\title{
Variability, Heritability and Genetic Advance Studies in F2 Generation of Cowpea (Vigna unguiculata sub sp. unguiculata)
}

\author{
G.R. Sabale*, S.G. Bhave, S.S. Desai, M.B. Dalvi and P.R. Pawar
}

Department of Botany, DBSKKV, Dapoli, College of Agriculture, Dapoli, Maharashtra, India

*Corresponding author

\section{A B S T R A C T}

\begin{tabular}{|c|}
\hline Keywords \\
\hline $\begin{array}{l}\text { Cowpea [Vigna } \\
\text { unguiculata (L.) } \\
\text { Walp.], GCV, PCV }\end{array}$ \\
\hline Article Info \\
\hline $\begin{array}{l}\text { Accepted: } \\
24 \text { August } 2018 \\
\text { Available Online: } \\
\text { 10 September } 2018\end{array}$ \\
\hline
\end{tabular}

An experiment was conducted with $23 \mathrm{~F}_{2}$ generation genotypes in randomized block design with three replication rabi season of 2017-18 at Research and Education farm, Department of Agriculture Botany, College of Agriculture, Dapoli. The estimates of phenotypic, genotypic and environmental variances revealed that, in general phenotypic variances for all the characters studied were higher than genotypic variances. Phenotypic coefficient of variation was greater than the genotypic coefficient of variation for all the characters for present study. The high phenotypic and genotypic coefficient of variation was observed for seed yield per plant, number of pods per plant, number of clusters per plant and number of primary branches per plant, while lowest GCV and PCV was observed for days to first flowering and days to maturity. High heritability with high genetic advance as percentage of mean was observed for seed yield per plant, number of pods per plant, plant height, number of primary branches per plant, hundred seed weight and harvest index. It indicates additive gene action and made it suitable for direct selection.

\section{Introduction}

Cowpea [Vigna unguiculata (L.) Walp.] is an annual, autogamous leguminous crop belonging to family Leguminoseae with a diploid chromosome number of $2 n=2 x=22$. It is native to India (Vavilov, 1949) but tropical and central Africa is also considered as secondary centre of origin where wild races are found even now ( $\mathrm{Ng}$ and Marechal, 1985).

Cowpea is cultivated around the world not only as a pulse but also vegetable crop. It has many common names including Black-eyed pea, Southernpea and Lobia. Cultivated cowpea varieties are adapted to hot and dry condition. Cowpea is tropical grain legume which plays an important nutritional role in developing countries of the tropics and sub tropics, especially in Sub-Saharan Africa, Asia, Central and South America (Singh et al., 1997).

Cowpea has been referred to as "Poor man's meat" because of its high protein content (20$25 \%$ ). Cowpea young leaves, pods and beans contain vitamins and minerals which have fuelled its usage for human consumption and animal feeding (Nielson et al.,1997) and considered as one of agriculture's oldest 
legume used as protein source for humans and livestock (Steele, 1972).

Dry seeds of cowpea are used to prepare several snacks and main meal dishes. It contains high amount of quality protein $(23.4 \%)$, carbohydrate $(60.3 \%)$, fat $(1.8 \%)$ and sufficient amount of calcium $(76 \mathrm{mg} / 100 \mathrm{gm})$, iron $(57 \mathrm{mg} / 100 \mathrm{gm})$ and vitamins such as thiamine $\quad(0.92 \mathrm{mg} / 100 \mathrm{~g}), \quad$ riboflavin $(0.18 \mathrm{mg} / 100 \mathrm{~g})$ and nicotinic acid $(1.9 \mathrm{mg} / 100 \mathrm{~g})$ (Chatterjee and Bhattaacharya, 1986). In India, the total area of pulses production is $72.3 \mathrm{~m}$ ha. with production of $64.4 \mathrm{~m} . t$ and productivity $890 \mathrm{~kg} / \mathrm{ha}$, where Maharashtra contributes a total production of 12\% (Anon., 2012).

On account of diverse uses of cowpea the varietal requirement in term of plant type, seed type, maturity, pattern of use and growth are diverse from region to region. Therefore cowpea breeding programme has become more complex and no single variety can be suitable for all the objectives (Barrett, 1987). Thus, there is need to develop varieties suitable for a specific region and or use. However, production is constrained by low and variable grain yield, seed quality, susceptibility to diseases and pests and the absence of improved cultivars. Under such circumstances genetic diversity is of great importance and plays a crucial role in focusing crop improvement.

\section{Materials and Methods}

The experiment was conducted in Randomized Block Design with $23 \quad \mathrm{~F}_{2}$ generation genotypes with three replications during rabi 2017-2018. The seed was dibbled at $30 \mathrm{~cm}$ distance between row to row and $20 \mathrm{~cm}$ distance between plant to plant. Each plot had $1.8 \mathrm{~m} \mathrm{x} \mathrm{1m} \mathrm{area} \mathrm{with} \mathrm{three} \mathrm{rows} \mathrm{for}$ each population. Each row contain 10 plants thus there were 30 plants per population, constitute 90 plants per cross in three replications. All the recommended package of practices and plant protection measures were followed timely to raise a good crop. Observations were recorded on twelve characters viz., days to first flowering, days to maturity, number of primary branches per plant, plant height $(\mathrm{cm})$, number of clusters per plant, number of pods per plant, number of pods per cluster, pod length $(\mathrm{cm})$, number of seeds per pod, 100 seed weight, harvest index and seed yield per plant.

The data available on individual characters were subjected to the method of analysis of variance commonly applicable to the randomized block design (Panse and Sukhatme, 1988).

\section{Coefficient of variation}

The genotypic and phenotypic coefficient of variation was calculated as per the formula given by Burton and De Vane (1953).

Genotypic coefficient of variation (GCV)

$\operatorname{GCV}(\%)=\frac{\sqrt{\sigma^{2} g}}{\bar{x}}$

Phenotypic coefficient of variation (PCV)

$\operatorname{PCV}(\%)=\frac{\sqrt{\sigma^{2} \mathrm{p}}}{\bar{x}}$

\section{Heritability}

Heritability in broad sense estimated for various characters by using the formulae suggested by Lush (1949). It was estimated from total genetic variances.

$\mathrm{H}^{2} \mathrm{~b}=\frac{\frac{\sigma^{2} g}{\sigma^{2} p}}{\sigma^{2}} \times 100$

\section{Genetic advance (GA)}

It was calculated in $\%$ by the formula suggested by Johnson et al., (1955). 
Genetic advance

G.A. $=\frac{\sigma^{2} g}{\sigma^{2} p} \times \sigma p \times K$

GA as per cent of mean

$\mathrm{GAM}=\frac{G_{A} A_{\mathrm{s}}}{\bar{x}} \times 100$

\section{Results and Discussion}

In present study, the genotypes exhibited a wide range of variation for all the characters under the study in cowpea. The analysis of variance revealed that the differences among genotype were substantial for all the characters studied (Table 1). The degree of variability varied considerably in different characters. The genotypes thus suitable for genetical studies as their contribution to the genotypic sums of squares were highly significant for all the characters. Considerable variation was observed for days to first flowering and days to maturity which indicated that the genotypes differed among themselves for these characters. In Konkan, cowpea is being grown after harvest of paddy crop in rabi season. Hence early varieties are required for cultivation in rabi season.

\section{Components of variation}

The total variability in each of the twelve characters could be partitioned into three components viz., phenotypic, genotypic and environmental variation (Table 2). Out of these, the genotypic variation is more important which helps to determine the heritable and non-heritable portion of variation with respect to characters under study. The result showed that phenotypic variance was higher than genotypic variance. The character plant height, number of pods per plant, harvest index and seed yield per plant showed high phenotypic and genotypic variance. Similar results were also reported by Idahosa et al., (2010), Manggoel et al., (2012), Massey et al., (2017) and Nair et al., (2017) in cowpea.

\section{Coefficient of variation}

Genotypic and phenotypic coefficients of variation are useful in detecting the amount of variability present in the available genotypes for particular character (Table 3). In general, the phenotypic coefficient of variation for all the characters was higher than genotypic coefficient of variation. It indicates the environmental influence on the genotype which may have effect to some extent on expression of the genotype.

The phenotypic coefficients of variation was high in number of primary branches per plant, number of clusters per plant, number of pods per plant and seed yield per plant which indicated that these characters were influenced by environmental factors. It was lowest for days to maturity and days to first flowering. Similar results were also reported by Kurer et al., (2010), Bhadru and Navale (2012) and Khan et al., (2015) in cowpea.

\section{Heritability and genetic advance}

The effectiveness of selection for any character will depend not only on the extent of genetic variability but also on extent to which it will be transferred from one generation to the next generation. High heritability of any character will give greater genetic advance under selection and accordingly a breeder will make his breeding strategies. Genetic advance gives magnitude of improvement per cycle in the base population by selection. That is heritability and genetic advance helps in determining the influence of environment in the expression of characters and the extent to which improvement is possible after selection.

In present study, high estimate of heritability in broad sense was observed for all the characters under study except for days to first flowering, days to maturity and number of pods per cluster. 
Table.1 Analysis of variance for the different characters studied in $\mathrm{F}_{2}$ generation of cowpea

\begin{tabular}{|c|c|c|c|c|}
\hline \multirow{2}{*}{$\begin{array}{l}\text { Sr. } \\
\text { No. }\end{array}$} & \multirow[t]{2}{*}{ Characters } & \multicolumn{3}{|c|}{ Mean sum of squares } \\
\hline & & $\begin{array}{l}\text { Replications } \\
\text { (2) }\end{array}$ & $\begin{array}{l}\text { Genotypes } \\
\text { (22) }\end{array}$ & Error (44) \\
\hline 1. & Days to first flowering & 9.91 & $10.81 * *$ & 4.71 \\
\hline 2. & Days to maturity & 6.27 & $21.48 * *$ & 7.00 \\
\hline 3. & Plant height $(\mathrm{cm})$ & 9.46 & $107.43 * *$ & 3.99 \\
\hline 4. & $\begin{array}{l}\text { Number of primary branches per } \\
\text { plant }\end{array}$ & 0.04 & $1.93 * *$ & 0.07 \\
\hline 5. & Number of clusters per plant & 0.16 & $4.83 * *$ & 0.17 \\
\hline 6. & Number of pods per cluster & 0.04 & $0.26 * *$ & 0.07 \\
\hline 7. & Number of pods per plant & 7.69 & $121.93 * *$ & 2.43 \\
\hline 8. & Pod length $(\mathrm{cm})$ & 0.12 & $3.17 * *$ & 0.48 \\
\hline 9. & Number of seeds per pod & 0.13 & $4.05^{* *}$ & 0.11 \\
\hline 10. & Hundred seed weight (g) & 0.13 & $7.59 * *$ & 0.13 \\
\hline 11. & Harvest index (\%) & 2.01 & $79.09 * *$ & 4.67 \\
\hline 12. & Seed yield per plant (g) & 2.14 & $214.88 * *$ & 3.59 \\
\hline
\end{tabular}

** Significant at $1 \%$ level

(Figures in parentheses denotes degrees of freedom)

Table. 2 Estimates of phenotypic $(\sigma 2 p)$, genotypic $(\sigma 2 g)$ and environmental $(\sigma 2 \mathrm{e})$ variance in $\mathrm{F}_{2}$ generation of cowpea

\begin{tabular}{|c|c|c|c|c|}
\hline $\begin{array}{l}\text { Sr. } \\
\text { No }\end{array}$ & Characters & $\sigma^{2} p$ & $\sigma^{2} g$ & $\sigma^{2} \mathrm{e}$ \\
\hline 1 & Days to first flowering & 6.74 & 2.03 & 4.71 \\
\hline 2 & Days to maturity & 11.82 & 4.82 & 7.00 \\
\hline 3 & Plant height $(\mathrm{cm})$ & 38.47 & 34.48 & 3.99 \\
\hline 4 & $\begin{array}{l}\text { Number of primary } \\
\text { branches per plant }\end{array}$ & 0.69 & 0.62 & 0.07 \\
\hline 5 & $\begin{array}{l}\text { Number of clusters per } \\
\text { plant }\end{array}$ & 1.72 & 1.55 & 0.17 \\
\hline 6 & Number of pods per cluster & 0.13 & 0.06 & 0.07 \\
\hline 7 & Number of pods per plant & 42.27 & 39.83 & 2.43 \\
\hline 8 & Pod length (cm) & 1.38 & 0.89 & 0.48 \\
\hline 9 & Number of seeds per pod & 1.42 & 1.31 & 0.11 \\
\hline 10 & Hundred seed weight (g) & 2.62 & 2.48 & 0.13 \\
\hline 11 & Harvest index (\%) & 29.48 & 24.80 & 4.67 \\
\hline 12 & Seed yield per plant (g) & 74.02 & 70.43 & 3.59 \\
\hline
\end{tabular}


Table.3 Estimates of genetic parameters for various characters in $\mathrm{F}_{2}$ generation of cowpea

\begin{tabular}{|c|c|c|c|c|c|c|}
\hline Sr. No & Characters & PCV (\%) & $\begin{array}{l}\text { GCV } \\
(\%)\end{array}$ & $\mathrm{H}^{2} \mathrm{bs}(\%)$ & GA & GAM (\%) \\
\hline 1 & Days to first flowering & 4.74 & 2.60 & 30.13 & 1.61 & 2.94 \\
\hline 2 & Days to maturity & 3.75 & 2.40 & 40.80 & 2.89 & 3.15 \\
\hline 3 & Plant height (cm) & 18.65 & 17.65 & 89.61 & 11.45 & 34.43 \\
\hline 4 & $\begin{array}{l}\text { Number of primary branches } \\
\text { per plant }\end{array}$ & 20.76 & 19.63 & 89.38 & 1.53 & 38.23 \\
\hline 5 & Number of clusters per plant & 26.17 & 24.83 & 90.00 & 2.43 & 48.52 \\
\hline 6 & Number of pods per cluster & 9.52 & 6.30 & 43.73 & 0.33 & 8.58 \\
\hline 7 & Number of pods per plant & 29.73 & 28.86 & 94.23 & 12.62 & 57.71 \\
\hline 8 & Pod length (cm) & 9.29 & 7.49 & 65.03 & 1.57 & 12.44 \\
\hline 9 & Number of seeds per pod & 11.74 & 11.27 & 92.10 & 2.26 & 22.28 \\
\hline 10 & Hundred seed weight (g) & 14.23 & 13.86 & 94.85 & 3.16 & 27.81 \\
\hline 11 & Harvest index (\%) & 15.77 & 14.47 & 84.15 & 9.41 & 27.34 \\
\hline 12 & Seed yield per plant (g) & 37.16 & 36.25 & 95.15 & 16.86 & 72.84 \\
\hline
\end{tabular}

Heritability estimates was highest for seed yield per plant (95.15) followed by hundred seed weight (94.85), number of pods per plant (94.23), number of seeds per pod (92.10), number of clusters per plant (90.00), plant height (89.61), number of primary branches per plant (89.38) and harvest index $(84.15 \%)$. Low estimates of heritability were observed for days to first flowering (30.13) and days to maturity (40.80). Similar results were reported by Thorat and Gadewar (2013) and Khan et al., (2015) in cowpea.

Genetic advance is a measure of expected progress under selection scheme. It gives the magnitude of improvement per cycle in the base population by selection. The genetic advance ranged between number of pods per cluster (0.33) to seed yield per plant (16.86). High genetic advance was recorded for seed yield per plant by Khan et al., (2015) and number of pods per plant by Thorat and Gadewar (2013) in cowpea.

Heritability alone provides no information on amount of genetic progress that would result from the selection. High heritability estimates along with high genetic advance as per cent was noticed in seed yield per plant, number of pods per plant, plant height, number of primary branches per plant, hundred seed weight and harvest index. The high heritability coupled with genetic advance reveals the presence of lesser environmental influence and prevalence of additive gene action in their expression. Hence seed yield per plant can be improved by selection in further generation. Similar result was reported by Thorat and Gadewar (2013), Sharma et al., (2017) and Das et al., (2018) for seed yield and Khan et al., (2015) for number of pods per plant in cowpea. High heritability with low genetic advance as per cent of mean for pod length and number of seeds per pod indicating these characters may be controlled by non-additive gene action. Similar results were recorded by Thorat and Gadewar (2013) for number of seeds per pod in cowpea.

\section{References}

Anonymous, (2012). FAO, FAOSTAT. Food and Agriculture Organization of the United Nations, Rome, Italy. 
Barrett, R. P. (1987). Integrating leaf and seed production strategies for cowpea [Vigna unguiculata (L.) Walp.] M.Sc. Thesis, Michigan State University, East, Lansing, M. I. USA, 391-396.

Bhadru, D. and P. A. Navale (2012).Genetic variability parameters in F2 and F3 populations of cowpea (Vigna unguiculata (L.) Walp.). Legume Res., 35 (1): $75-77$.

Burton, G. W and E. H. De Vane (1953). Estimating heritability in tall Fescue (Festuca arundinaceae) from replicated clonal material. Agronomy Journal.45: 478-481.

Chatterjee, B. N. and Bhattacharya, K. K. (1986). Principle and practices of grain legume production. Oxford and IBH publishing Co. Ltd., New Delhi.

Das, R.R., P. Talukdar, Praveen Kumar and S. B. Neog (2018) Relationship among different secondary traits and seed yield in cowpea (Vigna unguiculata L. Walp). Int.J.Curr.Microbiol.App.Sci 7(2): 1382-1396.

Idahosa, D. O., J. E. Alika and A. U. Omoregie (2010). Genetic variability, heritability and expected genetic advance as indices for yield and yield components selection in cowpea (Vigna unguiculata (L.) Walp).Academia Arena 2 (5).

Johnson, H. W., Robinson, H. F. and Comstock, R. F. (1955). Estimation of genetic environmental variability in soybean.Agronomy Journal, 47: 314318.

Khan, H., Viswanatha K. P. and H. C. Sowmya (2015). Study of genetic variability parameters in cowpea (vigna unguiculata L. walp.) germplasm lines. The Bioscan 10 (2): 747-750.

Kurer S., S. Gangaprasad, M.S. Uma, G. Shanthakumar and P.M. Salimath (2010). Genetic variability studies in F2 and F3 generations of cowpea (Vigna unguiculata (L.) Walp). Electronic Journal of Plant Breeding, 1(5) 13441346.

Lush, J. C., (1949).Heritability of quantitative characters in farm animals. Proceeding of 8th Congress hereditas. 28: 356-375.

Manggoel, W., Uguru, M.I., Ndam, O.N. and Dasbak, M.A. (2012). Genetic variability, correlation and path coefficient analysis of some yield components of ten cowpea [Vigna unguiculata (L.) Walp.] accessions. Journal of Plant Breeding and Crop Science, 4(5): 80-86.

Massey, P., Y.V. Singh and P. K. Singh (2017). Correlation and genetic variability studies yield components and thrip resistance in cowpea (Vigna unguiculata L.) TECHNOFAME- A Journal of Multidisciplinary Advance Research, 6(1), 51 - 57.

Nair, K. R., Desai S. S., Burondkar M.M. and Mane A.V. (2017) Correlation and path analysis studies in F2 generation of interspecific hybrids in cowpea (Vigna unguiculata ssp. unguiculata and vigna unguiculata ssp. sesquipedalis) G.J.B.B., 6 (3) 2017: 491-496.

Ng, N.Q. and Marechal, R. (1985).Cowpea taxonomy, origin and germplasm. In: Cowpea research, production and utilization. Singh, S.R. and Rachie, K.O. (eds.) Wiley, New York, 11-21.

Nielsen, S., Ohler, T. and Mitchell (1997). Cowpea leaves for human consumption, production, utilization and nutrient composition. In: Advances in Cowpea Research. Singh, B., Raj, Mohan, D. Dashiell, K. and Jackai, L. (Eds) International Institute of Tropical Agriculture (IITA) and Japan International Research Centre for Agricultural Sciences (JIRCAS), Ibadan, Nigeria, 326-332. 
Panse, V.G and P.V. Sukhatme, (1985). Statistical method for agricultural workers, 4th Edn., ICAR, New Delhi.

Sharma, M., P.P. Sharma, B. Upadhyay, H.L. Bairwa and D.R. Meghawal (2017).Character association and path analysis in cowpea [Vigna unguiculata (L.) Walp] Germplasm Line. Int.J.Curr.Microbiol.App.Sci6 (6): 786795.

Sing, R. K. and B. D. Choudhury, (1977). Biometrical methods in quantitative genetic analysis. Kalyani publishers, New Delhi.
Steele. W. M. (1972). Cowpea in Africa. Doctroal Thesis, University of Reading, United Kingdom.

Thorat, A. and Rajesh D. Gadewar (2013).Variability and correlation studies in cowpea (Vigna unguiculata). International Journal for Environmental Rehabilitation and Conservation, 4 (1) [44 - 49].

Vavilov, N. I. (1949). The origin, variation, immunity and breeding of cultivated plants. Chronica Botanica, 13:1-54.

\section{How to cite this article:}

Sabale, G.R., S.G. Bhave, S.S. Desai, M.B. Dalvi and Pawar, P.R. 2018. Variability, Heritability and Genetic Advance Studies in F2 Generation of Cowpea (Vigna unguiculata sub sp. unguiculata). Int.J.Curr.Microbiol.App.Sci. 7(09): 3314-3320. doi: https://doi.org/10.20546/ijcmas.2018.709.411 